\title{
THE HONOUR TO SERVE: RECOLLECTIONS OF AN UMKHONTO SOLDIER
}

\section{James Ngculu}

David Philip Publishers, Claremont, South Africa

2010, 272 pages,

ISBN 9780864867339

R 240

James Ngculu was one of those young South Africans who had chosen to dedicate their lives to the battle against apartheid. The 1976 uprising in Soweto motivated him to join Umkhonto we Sizwe (MK), the military wing of the African National Congress (ANC). During his years in exile, he occupied a variety of posts within the MK, which varied from Camp Politics Instructor, to Camp Commissar. He was also one of the founding members of the MK Military Intelligence wing, which played an important role in the struggle against apartheid. He also occupied an array of important governmental posts after the ANC's electoral victory in 1994. The honour to serve is a memoir of his time as a freedom fighter in the MK.

From the preface, it is clear that this book is a tribute to all the people who sacrificed their lives and time to fight for freedom from oppression. This book does not only intend to educate people on how the MK soldiers lived, trained and fought during the struggle, but also how they entertained themselves while waiting for action. Thus, it is a comprehensive recollection of the life of an MK soldier during the struggle.

Ngculu starts his story by explaining the harsh conditions that black people had to endure whilst growing up. These conditions ranged from living in shabby houses to being forced to attend school far from their family homes. Ngculu felt that that he had to do something to help black people to be treated as normal human beings; so, the Soweto uprising in 1976 was the last motivation that he needed to join an ANC unit. Ngculu then tells of his experience of leaving the country to fight with the MK in exile.

With this book, Ngculu illustrates how hard life was in the training camps

Scientia Militaria, South African Journal of Military Studies,

Vol 39, Nr 1, 2011, pp. 143-144.

doi: $10.5787 / 39-1-108$ of the MK soldiers. They had to endure rigorous training whilst sleeping and eating very little. At times, there was no water in the camps, so they were forced to fetch water from town or streams in the area. They basically 
had no luxuries in the camps but every now and then they would receive a shipment of Cuban cigars. Ngculu also tells how frustrated the MK soldiers were, because some of them spent years in the camps while waiting to be deployed to the front. This frustrated them because they were all there to fight the apartheid forces, but the ANC leadership was slow to deploy them to the fighting lines.

The author dedicates a chapter of the book to salute the women in the ANC and MK. He portrays the women who were in MK as selfless and courageous. The women had to endure the same training routines as the men and in some cases the women performed better than the men. Another chapter is dedicated to discuss how enemy agents infiltrated the ranks of the MK. They found that a network of spies and agent provocateurs were out to sabotage the MK as far as possible. Together with the enemy spies, the MK leadership also needed to stamp out the marijuana smoking that was taking place in the camps.

The last part of the book focuses on the time when the ANC was unbanned and the exiled freedom fighters could return home. A detailed discussion on the negotiations between the ANC and the apartheid regime with regard to the integration of MK into the defence force of South Africa forms part of the last segment of the book.

The fact that the book is written in plain English is definitely a positive point, because Ngculu wants every South African to understand what he had written. It was also enjoyable to read the speeches, published in the rear of the book, made by several of the MK leadership during the apartheid years and to see what the MK soldiers had to study during their stay in the training camps. It is clear that good research was done by the author before the writing of the book. On the negative side, the book comes across as slightly monotonous at times, especially in the last few chapters.

Overall, the book is a very educating read. It teaches how hardship and suffering can change to happiness and success if one is willing to fight for what you believe in. I would recommend this book to all the people of South Africa, because it tells the story of the men and women who sacrificed their lives and time to ensure that all the people of South Africa can enjoy freedom.

Lt E.T. Barnard, Department of History, Faculty of Military Science, Stellenbosch University 